\title{
Assessment of lead, copper and zinc contamination of soil from University of Cape Coast School of Agricultural farmland, Ghana
}

\author{
J. K. BENTUM ${ }^{1 *}$, J. P. K. ADOTEY ${ }^{1}$, J. KOKA ${ }^{1}$, E. J. KORANTENG-ADDO ${ }^{1}$, \\ Adomah YEBOAH ${ }^{1}$ and L. K. BOAMPONSEM ${ }^{2}$ \\ ${ }^{1}$ Department of Chemistry, University of Cape Coast, Ghana. \\ ${ }^{2}$ Department of Laboratory Technology, University of Cape Coast, Ghana. \\ * Corresponding author, E-mail: johnbentum@yahoo.com
}

\begin{abstract}
The extent of heavy metal contamination viz. lead $(\mathrm{Pb})$, copper $(\mathrm{Cu})$ and zinc $(\mathrm{Zn})$ in the soil of the University of Cape Coast School of Agricultural farmland, Ghana, were assessed. Thirty soil samples were taken from six demarcated areas in the farm. The mean metal concentrations (mean $\pm \mathrm{cv}$ ) and ranges of the metals were $(5.37 \pm 45.44) 1.93-11.88$ for $(\mathrm{Pb})$; $(2.52 \pm 118.9)$ 0.04-24.63 for $(\mathrm{Cu})$; $(475.87 \pm 26.54)$, 135.6887.01 and for $\mathrm{Al},(393.83 \pm 33.38)$ 138.32-1051.56. The results showed that the metal concentrations in the soil at six sites decreased in the order: $\mathrm{Zn}>\mathrm{Pb}>\mathrm{Cu}$. The variation in the distribution of the metals in the soil was found to be in the order $\mathrm{Cu}>\mathrm{Pb}>\mathrm{Zn}$. The enrichment factor indicated that the soil was enriched with the metals, and the extent of enrichment was in the order, $\mathrm{Zn}>\mathrm{Pb}>\mathrm{Cu}$. The geoaccumation index and the mean enrichment quotient indicated that the soil was polluted. This contaminated soil sediments could act as a source of pollutant for crops grown in the farm.
\end{abstract}

(c) 2011 International Formulae Group. All rights reserved.

Keywords: Heavy metal pollution, enrichment, soil.

\section{INTRODUCTION}

The accumulation of heavy metals in agricultural soils and crops raise concerns because they contribute toxic elements into the human food chain. Heavy metal contamination of soil results from anthropogenic source such as agriculture (Vaagalmaa and Conley, 2008; Srivastava et al., 2005; Igwe et al., 2005). Heavy metal pollution of soil enhances plant uptake causing accumulation in plant tissues and eventually phytotoxicity and change of plant community (Ernst 1996; Zayed et al., 1998;
Gimmler et al., 2002). According to Alloway et al. (1990), leafy vegetables generally tend to accumulate higher metal concentrations than root, grain or fruit crops. Vegetables contamination with heavy metals derives from factors such as the application of fertilizers, sewage sludge or irrigation with wastewater (Devkota and Schmidt, 2000; Mangwayana, 1995).

Furthermore, the uptake and bioaccumulation of heavy metals in vegetables are influenced by a number of factors such as climate, atmospheric 
depositions, the concentrations of heavy metals in soil, the nature of soil on which the vegetables are grown and the degree of maturity of the plants at the time of harvest (Lake et al., 1984; Scott et al., 1996; Voutsa et al., 1996). Certain trace elements are essential in plant nutrition, but crops, which are raised on the metal-contaminated soils, can accumulate metals in quantities that are excessive enough to cause clinical problems to both animals and human beings who consume these metal-riched plants (Tiller, 1986; Kabata-Pendias and Pendias, 1984; Alloway, 1990). Previous studies have shown that heavy metals are potentially toxic to crops, animals and humans when contaminated soils are used for crop production (Xian, 1989). Heavy metals may enter the human body through inhalation of dust, consumption of contaminated drinking water, direct ingestion of soil and consumption of food plants grown in metalcontaminated soil (Cambra et al., 1999; Dudka and Miller, 1999).

When the soils of farmland are polluted with zinc, animals will absorb concentrations that are damaging to their health. Watersoluble zinc that is located in soils can contaminate groundwater. Zinc cannot only be a threat to animals, but also to plant species. Due to the accumulation of zinc in soils, plants often have a zinc uptake that their systems cannot handle. Too much zinc can be harmful to health. According to VanMouwerik et al. (1998) and Lenntech (1998), too much zinc may cause poisoning in humans. Zinc is a component of tyres, which is released as they wear (Doss et al., 1995). Plant studies have shown that although $\mathrm{Zn}$ is an essential element for higher plants, it is considered phytotoxic in elevated concentrations, directly affecting crop yields and soil fertility. Soil concentrations ranging from $70-400 \mathrm{mg} / \mathrm{kg}$ total $\mathrm{Zn}$ is classified as critical, above which toxicity is considered likely (Alloway, 1990).

Lead $(\mathrm{Pb})$ levels in plants are to a large extent governed by air-borne $\mathrm{Pb}$ contamination which makes leaves and leafy vegetables most vulnerable to this airborne deposition (CCFAC, 1995). Shahi et al. (1997) identified exhausts from petrol-engine motor vehicles that use petrol lead as one of the major sources of $\mathrm{Pb}$ in soils. Lead from the atmosphere that lands on soils has low mobility and tends to stay in the top inch of soil. $\mathrm{Pb}$ in soil is poorly taken up by roots and is not transported away to the rest of the plant. Therefore, shallow-rooted plants, such as grasses and common vegetables, are particularly vulnerable to picking up lead contamination that originated in the atmosphere. About $7 \%$ of the lead in soil is taken up by plants; excessive lead will kill off the plants (Subhuti Dharmananda, 1997). In soils with $\mathrm{pH}$ of $>$ or $=5$ and with at least $5 \%$ organic matter, atmospheric lead is retained in the upper $2-5 \mathrm{~cm}$ of undisturbed soil (EPA, 1986).

Lead exposure is strongly associated with learning disorders and behavioural problems of children and the problems persist into adulthood (Mushak et al., 1989; Needleman et al., 1996, 2000). Women exposed to $\mathrm{Pb}$ during childhood subsequently pass the $\mathrm{Pb}$ onto the foetus during pregnancy and to the neonate during nursing (Gulson et al., 1998, 2002). In this way, $\mathrm{Pb}$ exposure is passed from generation to another and the problems become intergenerational legacy of the community (Mielke et al., 2004). Widespread $\mathrm{Pb}$ poisoning corresponds to IQ deficits, violent crimes and unwed pregnancies, all of which have implications to an array of social and psychological outcomes (Nevin, 2000). It may also lead to higher risks of heart attacks and strokes in adults. 
When copper ends up in soil, it strongly attaches to organic matter and minerals. As a result, it does not travel very far after release and it hardly ever enters groundwater. The effect of copper toxicity is largely on root growth and morphology. Copper tends to accumulate in the root tissue with little translocated to the shoots. Most copper compounds will settle and be bound to either water sediment or soil particles. Soluble copper compounds form the largest threat to human health. Usually water-soluble copper compounds occur in the environment after release through application in agriculture (Lenntech, 1995, 1998). Heavy metals exert toxic effects on soil microorganism (Pawlowska \& Charvat, 2004) hence results in the change of the diversity, population size and overall activity of the soil microbial communities (Smejkalova et al., 2003; Gupta, 1992; Hattori, 1996; Kelly et al., 2003).

Previous studies have shown that the soil in the University of Cape Coast School of Agriculture Farms have high levels of $\mathrm{Cu}$. This could be translocated to the crops grown on the land and render the crops hazardous for human consumption and also adversely affect cattle and sheep that feed on the land. Other metals, apart from $\mathrm{Cu}$ may be present due to the application of pesticides. The present study therefore was aimed at evaluating the pollution levels of $\mathrm{Cu}, \mathrm{Zn}$ and $\mathrm{Pb}$ in soil from the University of Cape Coast School of Agricultural farmland contaminated with heavy metals.

\section{MATERIALS AND METHODS}

\section{Sampling}

The selected site is a farm located at the northern section of the University of Cape Coast. The sites were chosen because previous studies revealed that the soil was enriched with cu; and the proximity of some sections of the farm to the road and potential for food crops to be polluted with heavy metals.

Soil and plant samples were collected from pre-selected sites A, B, C, D, E and F. Each sample site was divided into five areas before sampling. Ten samples of soils were collected at random at a depth of $0-20 \mathrm{~cm}$, from each of the demarcated areas using a garden trowel into a plastic container, mixed to obtain a homogenous sample and then placed into labeled plastic polyethylene bags for laboratory analysis. Five sets of samples were obtained from each of the six preselected sites.

\section{Sample treatment}

The soil was digested using the method described by MAFF (1981). Soil samples were air-dried and passed through $2 \mathrm{~mm}$ mesh. $1 \mathrm{~g}$ of each of the homogenized samples of soils was put into a $100 \mathrm{ml}$ beaker and 10 $\mathrm{ml}$ of concentrated $\mathrm{HNO}_{3}$ added. The mixture was heated until it almost dried. Further $10 \mathrm{ml}$ of $\mathrm{HNO}_{3}$ and $3 \mathrm{ml}$ of $\mathrm{HClO}_{4}$ were added and the solution heated and then allowed to evaporate to about 1-2 ml. $4 \mathrm{ml}$ of hot concentrated $\mathrm{HCl}$ was placed into a labeled plastic polyethylene bags for laboratory analysis added and then reflux for 10 minutes. Finally, the wall of the beaker was wash down with double distilled water, filtered in to a 50 $\mathrm{ml}$ volumetric flask, and diluted to the $50 \mathrm{ml}$ mark. All the digests and the blank solutions were analyzed for $\mathrm{Pb}, \mathrm{Cu}, \mathrm{Zn}$ and $\mathrm{Al}$ with an atomic absorption spectrometer (Spectr AA 220Fs, Varian). All experiments were carried out in duplicate.

In order to validate the precision of the analysis, reproducibility and recovery studies were carried out by analyzing double distilled water containing $1.0 \mathrm{ppm}$ of $\mathrm{Pb}, \mathrm{Zn}, \mathrm{Cu}$ and $\mathrm{Al}$ and samples spiked with $5.0 \mathrm{ppm}$ standards respectively. 
The statistically analysis of the data was done using Microsoft Excel 2007 and SPSS software (version 16.0 for Windows) Shapiro-Wilk test of normality was used to explore the data at 0,05 significance level; Spearman Rho method of regression and correlation was used to identify the relationship among metals.

\section{RESULTS AND DISCUSSION}

The results of precision and accuracy analysis are shown in Table 1 . The percentage recovery of the metals $\mathrm{Pb}, \mathrm{Cu}, \mathrm{Zn}$ and $\mathrm{Al}$, from the spiked samples were respectively $98.65 \%, 97.65 \%, 97.1 \%$ and $99.5 \%$. The results for the analysis of heavy metals in the soil from UCC School of Agricultural farmland are shown in Table 2 and Figure 1. The distribution of heavy metals at all the six sites follow a general trend, $\mathrm{Zn}>\mathrm{Pb}>\mathrm{Cu}$. There were variation trends in the levels of the metals at all the individual sites. The relative standard deviation (Table 2) showed that the variation in the distribution of the metals in the soil from the farmland was in the order $\mathrm{Cu}$ $>\mathrm{Pb}>\mathrm{Zn}$. The two sites $\mathrm{E}$ and $\mathrm{F}$ close to the road had the highest amounts of $\mathrm{Zn}$, with mean and ranges, in $\mathrm{mg} / \mathrm{kg}$, being respectively $588.39 \pm 150.54(413.46-809.17)$ and 550.18 \pm 202.26 (394.68-887.01), but had the lowest amounts of both $\mathrm{Pb}$ and $\mathrm{Cu}$. The levels of $\mathrm{Pb}$ and $\mathrm{Cu}$ at site $\mathrm{E}$ were respectively $3.62 \pm 0.62$ (2.31-3.91); and 0.20 \pm 0.68 (0.23-1.71), and at site $F$ the levels were respectively $3.83 \pm$ $0.24(3.69-4.27)$ and $2.28 \pm 0.23(1.24-3.75$. The overall mean concentrations (mean $\pm \mathrm{cv}$ ) and ranges of the metals in $\mathrm{mg} / \mathrm{kg}$ for all the sites were $\mathrm{Pb}, 5.37 \pm 45.44$ (1.93- 11.88); $\mathrm{Cu}$, $2.52 \pm 118.9(0.04-24.63) ; \mathrm{Zn}, 475.87 \pm 26.54$ (135.6-887.01) and $\mathrm{Al}, 393.83 \pm 33.38$ (138.32-1051.56). The $\mathrm{Cu}$ levels are comparable to previous findings.

The mean concentration of $\mathrm{Pb}, 5.37 \pm$ $0.45 \mathrm{mg} / \mathrm{kg}$, was within the acceptable limits of $\mathrm{Pb}=1-500 \mathrm{mg} / \mathrm{kg}$ (average $=50 \mathrm{mg} / \mathrm{kg}$ ) recommended by the Interdepartmental Committee on Reclamation of Contaminated Land (ICRCL, 1987) for heavy metals in soil used for agriculture, but much lower than the maximum tolerable levels proposed for agricultural soil (90-300 $\mathrm{mg} / \mathrm{kg} \mathrm{DW}$ ) by Kabata-Pendias and Pendias (1984). None of the samples had lead level greater than the recommended average. The mean concentration of $\mathrm{Zn}(475.87 \pm 0.27)$ was greater than the level recommended by Alloway (1990). Soil concentrations ranging from $70-400 \mathrm{mg} / \mathrm{kg}$ total $\mathrm{Zn}$ is classified as critical, above which toxicity is considered likely (Alloway, 1990). $73 \%$ of the samples had levels above the recommended limit, and $27 \%$ had levels within the limits set by Alloway. Copper levels were within the normal range of 2-250 $\mathrm{mg} / \mathrm{kg}$ recommended by Kabata Pendias and Pendias (1984) and also below $300 \mathrm{mg} / \mathrm{kg}$ recommended by EC (1986) and MAFF (1992). Generally the zinc levels were found to be above the normal range of $10-30 \mathrm{mg} / \mathrm{kg}$ observed by Logan (2000) and the $100 \mathrm{mg} / \mathrm{kg}$ given by EC (1986) and MAFF (1992). Regression and correlation analysis (Table 3 ) indicated that there were no significant relationships among the three metals at 0.05 and 0.01 confidence levels.

To evaluate the extent of contamination, the enrichment factor was calculated using the relation, $\mathrm{EF}=\left[\mathrm{C}_{\underline{n}} / \mathrm{C}_{\mathrm{ref}}\right] /$

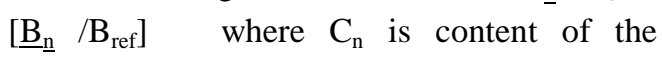
examined element in the examined environment, $\mathrm{C}_{\mathrm{ref}}$ is content of the examined element in the reference environment, $B_{n}$ is content of the reference element in the examined environment and $\mathrm{B}_{\text {ref }}$ is content of the reference element in the reference environment. Al was used as the reference element for normalization. Five contamination categories are recognized on the basis of the enrichment factors; EF $<2-$ 
depletion to minimal enrichment; $\mathrm{EF}=2-5-$ moderate enrichment; $\mathrm{EF}=5-20-$ significant enrichment; $E F=20-40$ - very high enrichment; EF > 40 - extremely high enrichment (Huu et al., 2010). EF values increase with increase contributions of the anthropogenic origins (Sutherland 2000). The enrichment factors (Table 4) showed that the soil is extremely enriched with $\mathrm{Pb}$ and $\mathrm{Zn}$ and significantly enriched with $\mathrm{Cu}$. The extent of enrichment was in the order $\mathrm{Cu}<\mathrm{Pb}<\mathrm{Zn}$. All the 30 samples indicated extremely high enrichment of $\mathrm{Zn} ; 22$ samples showed extremely high enrichment of $\mathrm{Pb}$ and 8- very high enrichment. For $\mathrm{Cu}, 3$ samples showed depletion to minimal enrichment of $\mathrm{Cu}$; 7moderate enrichment; 17- significant enrichment; 2 - very high enrichment and 1extremely high enrichment. A mean enrichment quotient (MEQ) for the three metals, which is determined by summing EFs for $\mathrm{Cu}, \mathrm{Pb}$, and $\mathrm{Zn}$ and dividing by three, was used to estimate the magnitude of humaninduced change in the soil on the farmland. The MEQ also indicated that the soil was contaminated. This observation is most likely due to the prolong application of fertilizers and other agricultural chemicals, particularly Koside 101 and topson. This observation is not strange as the application of agricultural chemicals on farms eventually enrich the soils with heavy metals.

Geo accumulation index (Igeo) was calculated using the formula Igeo $=\log _{2}$ $\mathrm{C}_{\mathrm{n}} / 1.5 \times \mathrm{B}_{\mathrm{n}}$ where $\mathrm{C}_{\mathrm{n}}$ is the measured concentration of the element in soil or sediment and $B_{n}$ is the geochemical background value and 1.5 is a constant (Mediola et al., 2008). The extent of pollution was classified as follows ; Igeo value of $<0$, Practically unpolluted; $0-1$, Unpolluted to moderately polluted; $1-2$, Moderately polluted; 2 - 3, Moderately to strongly polluted ; 3-4 strongly polluted and > 5 Very strongly polluted (Huu et al., 2010). The results indicated that the soil was not polluted with $\mathrm{Pb}$ and $\mathrm{Cu}$ but was moderately polluted with $\mathrm{Zn}$. Also none of the individual samples was found to be polluted with $\mathrm{Cu}$ or $\mathrm{Pb}$.

Pollution load index (PLI) for the entire sampling site was determined as the nth root of the product of the $n$ contamination factors $(\mathrm{CF}) . \mathrm{PLI}=\left(\mathrm{CF}_{1} \times \mathrm{CF}_{2} \times \mathrm{CF}_{3} \times \cdots \times \mathrm{CFn}\right)^{1 / n}$. This empirical index which provides a simple, comparative means for assessing the level of heavy metal pollution according to Usero et al. (2000), revealed that polluted soil has a value of PLI $>1$.

Table1: Recovery of metal from 1.0 ppm standard.

\begin{tabular}{lcccc}
\hline Variable & \multicolumn{4}{c}{ Metal (ppm) } \\
\cline { 2 - 5 } & $\mathbf{P b}$ & $\mathbf{C u}$ & $\mathbf{Z n}$ & Al \\
\hline Mean & 0.996 & 0.986 & 0.981 & 0.996 \\
sd & 0.017 & 0.03 & 0.011 & 0.017 \\
CV & 1.706 & 3.043 & 1.121 & 1.706 \\
Std. Error & 0.005 & 0.009 & 0.003 & 0.005 \\
\hline
\end{tabular}


Table 2: Concentration of $\mathrm{Pb}, \mathrm{Cu}, \mathrm{Zn}$ and $\mathrm{Al}$ is Soil.

\begin{tabular}{|c|c|c|c|c|}
\hline Sample & $\mathbf{P b}$ & $\mathbf{C u}$ & $\mathbf{Z n}$ & Al \\
\hline $\mathrm{A} 1$ & 11.25 & 2.04 & 341.04 & 374.12 \\
\hline $\mathrm{A} 2$ & 6.71 & 1.78 & 250.45 & 337.57 \\
\hline $\mathrm{A} 3$ & 11.88 & 12.13 & 513.32 & 1051.56 \\
\hline A4 & 10.88 & 24.63 & 541.75 & 569.11 \\
\hline A5 & 8.12 & 1.67 & 492.95 & 569.71 \\
\hline B1 & 9.77 & 1.18 & 135.36 & 188.32 \\
\hline B2 & 1.93 & 2.1 & 158.6 & 138.32 \\
\hline B3 & 4.42 & 1.17 & 341.81 & 416.79 \\
\hline B4 & 3.53 & 0.84 & 265.85 & 301.51 \\
\hline B5 & 3.6 & 2.37 & 379.91 & 352.69 \\
\hline $\mathrm{C} 1$ & 5.58 & 0.94 & 414.71 & 444.2 \\
\hline $\mathrm{C} 2$ & 11.77 & 5.61 & 454.62 & 318.9 \\
\hline $\mathrm{C} 3$ & 7.93 & 0.01 & 518.49 & 330.25 \\
\hline $\mathrm{C} 4$ & 3.84 & 0.81 & 350.23 & 182.14 \\
\hline C5 & 3.83 & 0.81 & 530.82 & 272.52 \\
\hline D1 & 4.94 & 0.86 & 600.17 & 286.17 \\
\hline D2 & 3.66 & 1.97 & 442.74 & 172.65 \\
\hline D3 & 5.38 & 0.79 & 670.24 & 359.2 \\
\hline D4 & 3.57 & 1.33 & 667.79 & 288.99 \\
\hline D5 & 2.91 & 0.04 & 512.47 & 160.44 \\
\hline E1 & 3.31 & 0.8 & 413.46 & 417.71 \\
\hline $\mathrm{E} 2$ & 3.36 & 1.57 & 595.25 & 611.59 \\
\hline E3 & 3.17 & 0.23 & 491.76 & 273.3 \\
\hline E4 & 3.71 & 1.69 & 809.17 & 505.7 \\
\hline E5 & 3.91 & 1.71 & 632.29 & 501.47 \\
\hline $\mathrm{F} 1$ & 3.76 & 2.44 & 472.08 & 328.75 \\
\hline $\mathrm{F} 2$ & 3.74 & 2.03 & 394.68 & 445.22 \\
\hline F3 & 3.71 & 1.24 & 413.21 & 305.8 \\
\hline $\mathrm{F} 4$ & 3.69 & 3.75 & 583.92 & 634.19 \\
\hline F5 & 4.27 & 1.93 & 887.01 & 676.33 \\
\hline
\end{tabular}

Table 3: Correlation matrix for elements in the soils of study area.

\begin{tabular}{ccccc}
\hline & & $\mathrm{Pb}$ & $\mathrm{Cu}$ & $\mathrm{Zn}$ \\
\hline $\mathrm{Pb}$ & Correlation Coefficient & 1 & & \\
& P-value &. & & \\
$\mathrm{Cu}$ & Correlation Coefficient & 0.262 & 1 & \\
& P-value & 0.162 &. & \\
$\mathrm{Zn}$ & Correlation Coefficient & 0.017 & -0.042 & 1 \\
& P-value & 0.927 & 0.827 &. \\
& $\mathrm{~N}$ & 30 & 30 & 30 \\
\hline $\mathrm{P}=0.05$ & \multicolumn{3}{c}{} \\
& \multirow{2}{*}{1708} & &
\end{tabular}


Table 4: Summary of mean Igeo, and mean EF.

\begin{tabular}{lll}
\hline Metal & mean EF & mean Igeo \\
\hline $\mathrm{Pb}$ & 63.32 & -2.66 \\
$\mathrm{Cu}$ & 11.12 & -5.74 \\
$\mathrm{Zn}$ & 908.6 & 1.63 \\
\hline
\end{tabular}

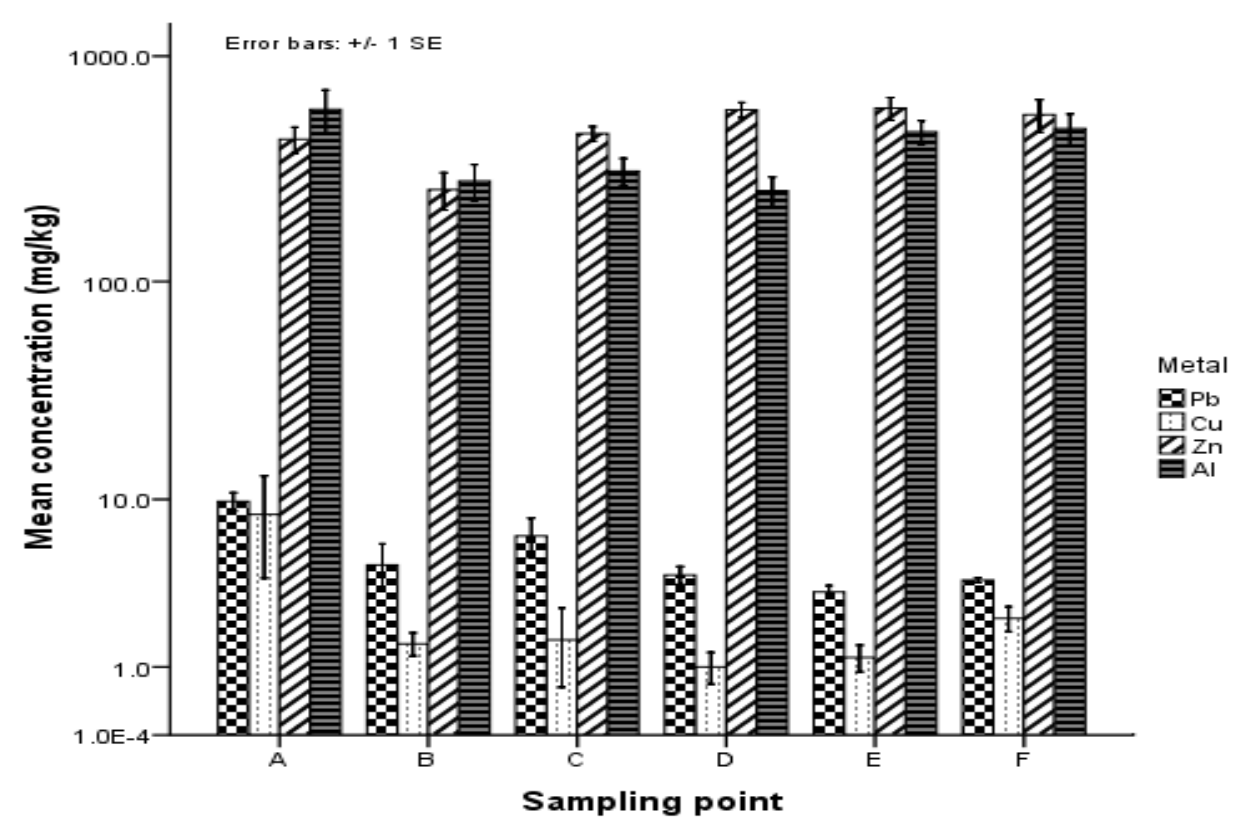

Figure 1: Mean concentrations of metals at the sampling sites.

\section{Conclusion}

In conclusion, $\mathrm{Zn}$ levels in the soil of the University of Cape Coast, School of Agricultural farm is remarkably high, but varied within the farmland. Our results suggest that special attention must be given to the need to control the use of agricultural chemicals, because a large portion of metals in the soil sediments are likely to be translocated into food crops grown on the soil.

\section{REFERENCES}

Alloway BJ, Jackson AP, Morgan H. 1990.

The accumulation of Cadmium by vegetables grown on soils contaminated from a variety of sources. Sci. Tot. Environ., 91: 223-236.

CCFAC. 1995. Revised discussion paper on $\mathrm{Pb}$. Codex Committee on Food Additives and Contaminants CX/FAC., 95(18): 2

CRCL. 1987. Interdepartmental Committee for the redevelopment of contaminated Land. Guidance on the Assessment and Redevelopment of Contaminated Land Paper 59(83) $2^{\text {nd }}$ Ed. Department of the Environment, London.

Datta SP, Biswas DR, Saharan N, Ghosh SK, Rattan, RK. 2000. Effect of ion term 
application of sewage effluents on organic carbon, bioavailabe phosphorus, potassium and heavy metals status of soils and uptake of heavy metals by crops. J. Indian Soc. Soil Sci., 48: 836 839.

Devkota B, Schmidt GH. 2000. Accumulation of heavy metals in food plants and grasshoppers from the Taigetos Mountains, Greece. Agric. Ecosyst. Environ., 78: 85-91.

Dudka S, Miller WP. 1999. Permissible concentrations of arsenic and in soils based on risk assessment. Water Air Soil Pollut., 113: 127-132.

EC (Commission Regulation). 2001. Setting maximum levels for certain contaminants in food stuffs. Official Journal of the European Communities, 466:

EC (Council of the European communities). 1986. Directive, 86: 278

EPA. 1986. Environmental Protection Agency. Air quality criteria for lead, June 1986 and Addendum, September 1986. Research Triangle Park, N.C. EPA 600(8): 83-018F.

Ernst. 1996. Bioavailability of heavy metals and decontamination of soils by plants. Appl. Geochem., 11: 163-167.

Frost HL, Ketchum LH. 2000. Trace metal concentration in durum wheat from application of sewage sludge and commercial fertilizer. Adv. Environ. Res., 4: 347-355.

Gimmler H, Carandang J, Boots A, Reisberg E, Woitke M. 2002. Heavy metal content and distribution within a woody plant during and after seven years continuous growth on municipal solid waste (MSW) bottom slag rich in heavy metals. J. Appl. Bot., 76: 203-217

Gulson BL, Jameson W, Mahafey KR, Mizon KJ, Patison N, Law AJ, Korsch MJ. 1998. Relationships of lead in breast milk to lead in blood, urine, and diet of the infant and mother. Environ. Health Perspect. 106: 667-674.
Gulson BL, Mizon KJ, Smith H, Eisman J, Palmer J, Korsch M, Donnelly J, Waite K. 2002. Skeletal lead release during bone resorption: effect of biphosphonate treatment in a pilot study. Environ. Health Perspect. 110:1017-1023.

Huu HH, Rudy S, Van Damme. 2010. Distribution and contamination status of heavy metals in estuarine sediments near Cau Ong harbor, Ha Long Bay, Vietnam. Geology Belgica, 13(1-2): 37 - 47

Igwe JC, Nnorom IC, Gbaruko BCG. 2005. Kinetics of radionuclides and heavy metals behaviour in soils: Implications for plant growth. African Journal of Biotechnology, 4(B):1541-1547.

Interdepartmental Committee on Reclamation of Contaminated Land (ICRCL). 1987. Guidance on the Assessment and Redevelopment of contaminated Land. Paper 59: $832^{\text {nd }}$ Ed. Department of Environment, London.

Kabata-Pendias A, Pendias H. 1984. Trace elements in soils and plants. CRC Press Boca Raton Fla., 85: 107 - 129.

Lake DL, Kirk PWW, Lester JN. 1984. The fractionation characterization and speciation of heavy metals in sewage sludge and sewage amended soils. Journal of Environmental Quality, 13: 175-183.

Logan TJ. 2002. Soil and environmental quality. In Anikwe MAN.

Mangwayana ES. 1995. Heavy metals pollution from sewage sludge and effluent of soil and grasses at Crowborough Farm. B. Sc. Thesis, University of Zimbabwe, p. 63.

Mediolla LL, Domingues MCD, Sandoval MRG. 2008. Environmental assessment of and active tailings pile in the State of Mexico (Central Mexico). Research Journal of Environmental Sciences, 2(3): $197-208$.

Mielke HW, Berry KJ, Mielke PW, Powell ET, Gonzales CR. 2004. Multiple metal ccumulation as a factor in learning 
achievement within various New Orleans Elemental Research. Article in Press.

Ministry of Agriculture, Fisheries, Food, and Welch Office Agriculture Department. 1992. Code of Good Agriculture Practice for the Protection of Soil. Draft Consultation Document, MAFF, London Mushak P, Davis JM, Crocetti AF, Grant LD. 1989. Prenatal and postnatal effects of low-level lead exposure integrated summary of a report to the US congress on childhood lead poisoning. Environ. Res., 50: 11-36.

Needleman HL, Schell A, Bellinger D, Leviton A, Allred EN. 1991. The long term effects of exposure to low doses on lead in childhood: An Eleven Year
Follow Up Report. New England Journal of Medicine, 322(2): 83-88.

Nevin R. 2000. How lead exposure relates to temporal changes in IQ, Violent Crime, and Unwed Pregnancy. Environ. Res., 83: $1-22$.

Srivastava R, Kumar D, Gupta SK. 2005. Municipal sludge-induced phytotoxicity. ATLA, 33: 501-508.

Tiller KG. 1986. Essential and toxic heavy metals in soils and their ecological relevance. Trans. XIII Congr. Intern. Soc. Soil Sci., 1: 29-44.

Zayed A, Lytle CM, Qian JH, Terry N. 1998. Chromium accumulation, translocation and chemical speciation in vegetable crops. Planta, 206: 293-299. 